\title{
Jiyūgaoka as Women's Realm: A Case Study on Tokyo Genderfication
}

\author{
Noemí Gómez Lobo, \\ Yoshiharu Tsukamoto, \\ Diego Martín Sánchez
}

\begin{abstract}
Framed within the question of how gender influences the production of urban space, this study reveals how Jiyügaoka, a high-end suburban area in Tokyo, has developed by targeting a particular gender role: women as caretakers and consumers. Car-safe and bike-friendly, Jiyügaoka pedestrian areas have more greenery, pavement, and urban furniture in comparison with the average Tokyo street. Jiyügaoka spatial practices encourage the meeting of people in the public realm, creating relationships between behaviors and their supporting physical environment. By aiming at women, other non-normative bodies were rendered into the city, enhancing public life and creating an accessible milieu. Jiyūgaoka genderfication process, by which the overlaying of commercial and gender mechanisms has impacted urban phenomena, is shown through a chronological investigation of gender-charged contents and its mapping in the urban fabric. This study demonstrates how urban transformation in Jiyūgaoka has encompassed changes in the lives of women in Japanese society. Representative examples from each period illustrate the physical translation of this development, from a home cooking school to a promenade with hundreds of benches.
\end{abstract}

Keywords: behaviorology, gender studies, genderfication, gentrification, Tokyo urbanism

In the last one hundred years, Jiyūgaoka has developed from rice paddies to a bustling neighborhood by targeting a primary user: women as consumers. Jiyūgaoka is part of Tokyo's unique spatial structure, consisting 
of a dense landscape of single-family houses connected by train to corporate centers. The gentrifying effect of adjusting to a female clientele led to the proliferation of contents associated with the feminine realm in Japan, such as sweetshops, fashion boutiques, and beauty salons. In parallel, the environment gradually changed into pedestrian roads with lots of greenery and benches, creating an intergenerational and lively public realm. This double condition that renders profitability as livability calls into question the entanglement between gender and gentrification as simultaneously registering some identities while excluding other non-heteronormative or economically challenged groups. The question posed by this study is how has Jiyūgaoka's transformation reflected changing notions of a particular gender role in Japan, namely "the housewife." The assumptions about women's performativity in Japanese society varied from the "good wife and wise mother" (ryōsai kenbo) to a younger generation of university students and working professionals. ${ }^{1}$ Jiyūgaoka's growth has encompassed these shifting behaviors of women in the city, affecting Tokyo's urbanism. This study aims to clarify how this development - termed "genderfication" for the overlapping of gender and commercial processes - has taken shape in the urban fabric over time, creating locally rooted architectural solutions.

\section{INTRODUCTION: REDEFINING GENDERFICATION THROUGH JIYŪGAOKA}

The neologism genderfication has emerged in recent years in the literature of pedagogical and sociological studies, presenting different meanings depending on the field of research. Under the inquiry of queer studies and education, Anne Harris and Stacy Holman Jones refer to genderfication as the flattening of queer subjectivities into mainstream heteronormativity and gayness. ${ }^{2}$ In the field of political sociology and urban studies, Marguerite van den Berg points to genderfication as "the production of space for post-Fordist gender notions." ${ }^{3}$ The new urban planning encouraged by the state that regulates the exodus of a creative class with equal double income to the city downtown identified in van den Berg as genderfication becomes a narrow definition for this particular analysis in the Japanese context. Social changes in the neoliberal metropolis of Tokyo include more women working, but still with a wage gap compared with the male population and performing the majority of domestic chores. The number of urban singles is growing while families with children are decreasing. Also, Jiyūgaoka's improvement of public space aiming at women and families has been a transformation through local commerce, in contrast to the government planning strategy led by experts in European cities.

In this article, genderfication also refers to the production of space for changing gender notions but without limiting its understanding to the western post-Fordist city. The notion of gentrification finds nuances in Jiyūgaoka's case. While in western contexts, gentrification usually refers to the displacement of social groups by affluent ones, Jiyūgaoka developed 
as an upper-class suburban area directly from agricultural land. This study proposes the use of genderfication as the urban transformation through which the intertwining of gender and commercial mechanisms impact urban phenomena. Genderfication differs from gentrification in that the production of space is not only oriented towards economically affluent social groups but is also exploiting a specific gender role as a market niche. An example of genderfication towards men could be the development of a male entertainment district. Jiyūgaoka's case is remarkable for being a genderfication process with women as the target group and driven by a bottom-up transformation from local commerce, which has produced a high-quality urban space.

Daphne Spain introduced "gendered spaces" as the segregation of the sexes in institutionalized spaces such as prisons or schools. ${ }^{4}$ Although Spain's discussion also exemplifies department stores as "spaces created by the private and public sectors that become gendered through their clientele," 5 this article includes the term "charged" to reinforce their voluntary status by differentiating them from a binarized condition. The gender-charged notion refers to those contents that have a stereotypical association with the feminine or masculine realm, yet are voluntary and not mandatory in their gender separation. The methodology builds in the revised literature using the notions of "genderfication" and "gender-charged." Also, behaviorology theory is especially relevant for this research since it goes beyond a functionalist point of view to address multiple concerns of the complex urban dimension (human, environmental, and architectural). ${ }^{6}$ Under the behaviorology lens, gender matters in the study of the city and its spatial quality. Considering a time frame of more than fifty years, the characteristics of urban morphology become apparent. This method does not apply solely to human behavior and its influence in shaping the physical environment but also relates explicitly to urban space. The behavior of Jiyūgaoka itself can be unveiled.

The article continues the discussion of Tokyo from a gender perspective and Jiyūgaoka as a first-generation suburban area, along with an overview of the evolution of women's roles in Japan. This specific socio-cultural context informs the further investigation of the gender-charged contents documented in the Jiyūgaoka Shopping Association Guidebook from the 1960s to the present. These contents are mapped chronologically in the urban fabric, revealing where gender-charged areas have accumulated. Representative examples of female-charged areas illustrate the materialization of Jiyūgaoka's genderfication process, to finally understand how changing gender notions of the Japanese women were rendered into the city.

\section{BACKGROUND: GENDER PERSPECTIVE ON THE JAPANESE CONTEXT}

Gender studies at their intersection with the urban realm is a matter of interdisciplinary scholarship. Sociologists pioneered the debate on women and cities in the early 1980 s, followed by geographers, architects, urban 
planners, and historians. ${ }^{7}$ With a Lefebvrian understanding of space not as a container but as a reflection of social relations, ${ }^{8}$ and considering gender as a social, cultural, and temporal construct, ${ }^{9}$ gender norms began to be studied in their influence on the production of space. The gender perspective showed how the sexual division of labor informs the spatial structure of cities. The business city center was associated with male productivity, while the residential periphery was linked to the reproductive activities carried out by women. ${ }^{10}$ In the 1990s, the city also became examined as the place of women's emancipation. ${ }^{11}$ With the turn of the twenty-first century, the discussion of gender and contemporary urban environments has expanded to include LGTBQ realities. ${ }^{12}$ Despite this advancement, the vast majority of the research on the urban from gender perspectives has still focused on Western contexts.

While disciplines like sociology or geography have explored the relations between urban conditions and gender roles in Japanese society, ${ }^{13}$ the fields of architecture and urbanism have overlooked this analysis. ${ }^{14}$ In Japan, the separation of productive and reproductive spheres, represented by a business downtown of breadwinners and a residential suburban area of homemakers, consolidated during the rapid economic growth after the Second World War. The sociologist Emiko Ochiai traces its roots back to the Taisho Period (1912-1926) just when rapid industrialization followed First World War:

This new middle class created a new lifestyle: that is, they moved to the residential suburbs, which were being developed on the outskirts of large cities, and from there, the husband commuted to their downtown offices on the newly built streetcar lines. With this separation of workplace and home, and thus of the public and private realms, wives of this class took on the title of the cloistered okusan, who had looked after the domestic affairs in her husband's absence. ${ }^{15}$

The okusan that Ochiai refers to is the wife of the warrior class (samural) and therefore belongs to a wealthy elite. When Tokyo was still known as Edo and society was highly hierarchical, these women who stayed at home were just one of the many social groups that conformed to Japanese society. Other women from different social strata, such as farmers or merchants, were engaged in productive labor. ${ }^{16}$ It was not until the Meiji restoration in 1868 that Tokyo started the transformation from a feudal society to a modern city, and only after Second World War that the full-time housewife (sengyō shufu) became the gender norm. ${ }^{17}$

In Tokyo, a distinctive transportation system sewed this construction of the female and male realms. Unlike the car-centered infrastructure characteristic of archetypal suburbs, the railway network allowed Tokyo to grow without strict urban laws or master plans. ${ }^{18}$ This mobility system connected the scenario of the "salaryman" who commutes to the business center, usually 
located inside the train loop known as the Yamanote Line, with the everchanging landscape of detached houses mainly inhabited by women during the daily hours. ${ }^{19}$ Commercial streets (shōtengai) formed around the multi-core system of stations, containing not only basic needs related to care, such as nurseries or health clinics, but also leisure and consumption activities such as restaurants or fashion stores.

Consequently, a functional tool for basic transportation needs appeared as complementary of the train: the mamachari, a utility bike. This "mom's bike" is generally electric-assisted and equipped with baskets and seats for up to two infants. As the car is not the primary means of transportation, suburban zones are tranquil quarters. Here, women operate on a neighborhood scale, making their daily groceries, taking their children to school, and participating in community activities. ${ }^{20}$ In these suburbs of care, where mobility occurs mainly by foot or cycling, the roads are generally safe. However, residential Tokyo streets are lackluster and thought only for transit. Furniture as ordinary as a bench is a rarity. This absence of places to rest in Tokyo's hilly topography can be a hardship for those who have difficulty moving or are taking care of children. The case of Jiyūgaoka presents features that are vital for defining urbanism from a gender perspective, such as safe pedestrian itineraries and inclusive spaces. ${ }^{21}$

\section{Jiyūgaoka: A First-Generation Suburbia for Wealthy Women}

Among the first-generation of Tokyo suburbs that began to surface in the early twentieth century, Jiyūgaoka ranks as one of the three favorite neighborhoods to live, being double the average land price of Tokyo. ${ }^{22} \mathrm{~A}$ significant cause is Jiyūgaoka's strategic location, right at the midpoint of the train line that connects the productive hubs of Tokyo and Yokohama - Tokyu-Toyoko Line (Fig. 1a). Jiyūgaoka has gained fame as the ideal town for women, due to its contents deeply related to the feminine realm in Japan. Additionally, Jiyūgaoka has unique urban characteristics in comparison to other Tokyo suburbs. Cobblestone paths and numerous benches form the commercial core that surrounds the station. This cluster of accessible streets was nicknamed as "pedestrian heaven" (Fig. 1b). An exceptional case of Jiyūgaoka is the existence of a free circular bus that only runs through the neighborhood by reusing waste oil as fuel. In 2012, the Japanese government awarded the area for its urban quality. The architectural historian Hidenobu Jinnai declared as part of the jury:

The collection of high-quality urban spaces makes Jiyūgaoka a town that can be easily walked and enjoyed. A fascinating and varied landscape is created from the redesign of narrow streets and existing alleys with diverse expressions, taking advantage of the characteristics of the small scale. There is a lively and comfortable feeling in the commercial area, where green and benches are placed ubiquitously, creating a place for people to enjoy a sense of slowness. ${ }^{23}$ 
Jiyūgaoka has changed through time, consolidating today as a vibrant women-oriented neighborhood. The previously existing agricultural village of Fusumamura began its transformation from productive farmland to residential suburbia after $1923 .{ }^{24}$ At the time, two main events accelerated the expansion process: The Great Kantō earthquake and the opening of the current Meguro Line. After the disaster, people seeking refuge built their homes where rice fields and bamboo groves used to exist, and the railway development triggered urban growth. In 1927, the Kuhonbutsu station was built and soon changed its name to Jiyūgaoka after the establishment of Jiyūgaoka Gakuen school in the near premises. The term Jiyū means "liberty," and the school was a pioneer for promoting freedom of education. During this period, many intellectuals and artists gathered in the area following the free spirit of modernization, thus starting Jiyūgaoka's reputation as a cultural village. ${ }^{25}$

However, in 1945, the Great Tokyo Air Raid burned most of the commercial streets that had spread in front of the station into ashes. ${ }^{26}$ After the economic growth that followed the Second World War, multiple shops and services aimed at female customers progressively flourished, transforming Jiyūgaoka into a specialized neighborhood for women. ${ }^{27}$ This image of a high-end suburban area, linked to fashion and sweets, was encouraged by the media. The retrofitting loop between the image of the city and the real urban fabric began in the 1960s, after the best-seller novel "Mrs. Jiyūgaoka." ${ }^{28}$ Soon after,
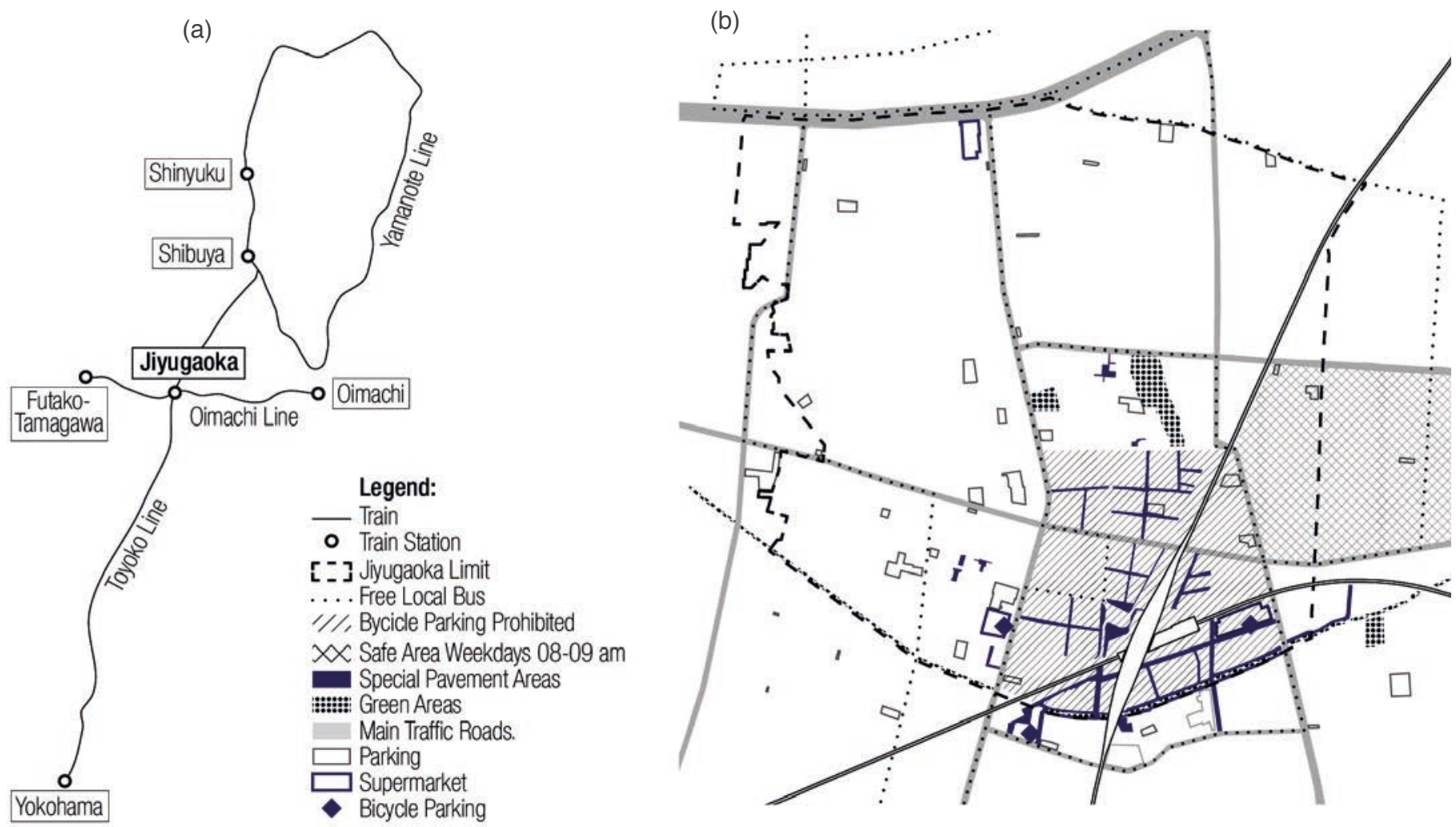

Figure 1. Jiyūgaoka mobility. Connected by train to the main productive centers since 1927 (a), the area around the station has been progressively transformed into a "pedestrian heaven" (b). 
this story of the bourgeoisie housewives' life in Jiyūgaoka was brought to the movies. ${ }^{29}$ In the 1970s, a growing number of women's magazines started to feature Jiyūgaoka's as a place for young ladies. One of them is the magazine Hanako, launched in 1988 and very popular among women in their '20s and '30s, which has been publishing a special issue on Jiyūgaoka every year since $2008 .{ }^{30}$

\section{The Evolution of Women's Roles in Japan}

In order to understand the changes in the lives of Japanese women, it is necessary to look at historical data regarding work and marriage. Observing the women labor in Japan graph (Fig. 2a), it is noticeable that a low peak was produced in the first decades of the working life. In the '60s and '70s, women stopped working, returning to the labor market in low-skilled jobs in later stages of life. Having fewer children and getting married later in life has caused the peak of the "M" shape curve to flatten in recent decades. The average age of marriage has risen from 24 years old in the 1960s to almost 30 years old in the 2010 s. However, the percentage of married women has slightly dropped from almost $100 \%$ until the 1970 s to approximately $90 \%$ in the 2010s. ${ }^{31}$ Even though the working conditions of women have improved, the type of employment is mainly temporary. ${ }^{32}$ In 2017 women participating in the labor market as part-timers doubled men. ${ }^{33}$ Looking at time spent in housework in Japan (Fig. 2b), it is remarkable that while women's time is tripartite between work, housework, and leisure, men lead a dual life between work and leisure. This diagram indicates that despite participating actively in the workforce, women are still responsible for the majority of the housework in contemporary Japanese society. ${ }^{34}$

This data explains how women in Japan underwent a "housewification" process in the post-war years of high economic growth, reinforcing the gender division of labor. ${ }^{35}$ Furthermore, only after the bubble burst, conventional roles began to be questioned, and new lifestyles flourished. These new women from the 1980s were active in the public sphere. Empowered by regulations that, despite having flaws, helped improve their position in society, such as the Equal Employment Opportunity Act implemented in 1986. Criticism of the women's role in Japanese society finds its roots in feminist movements of the early '70s, better known as uman ribu (women liberation). Later in the '80s, this grass-root activism transferred to the academy with the new term feminisumu (feminism). Since then, many Japanese feminist activists have been demanding a higher social assessment of care work, better urban spaces, childcare assistance, and addressed environmental issues. ${ }^{36}$

\section{METHODOLOGY: CHRONOLOGICAL INVESTIGATION OF A LOCAL GUIDEBOOK AND EMPIRICAL OBSERVATION THROUGH DRAWINGS}

Behaviorology is a means to understand the built environment across different scales, social and physical, positioning the urban within an 
(a)

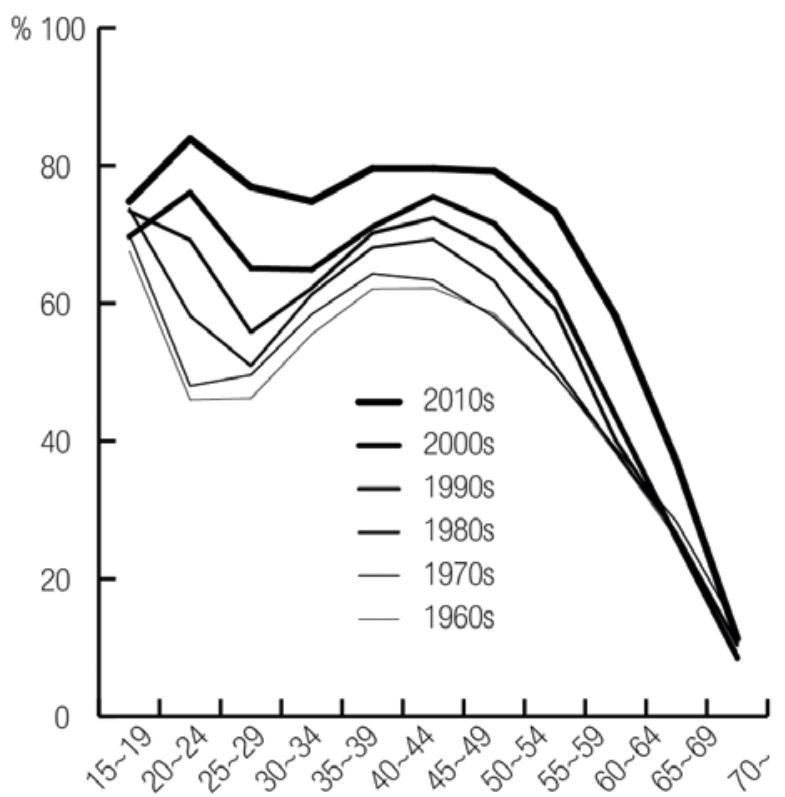

(b) Hours 18

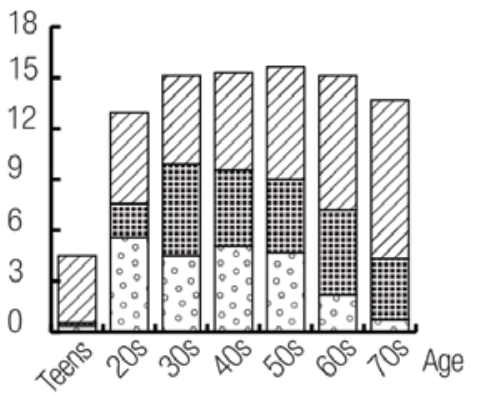

Hours

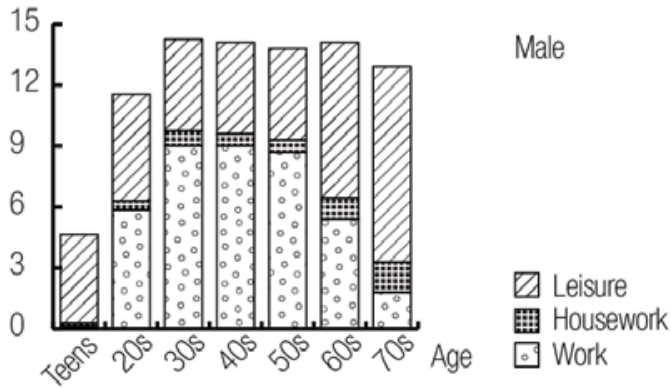

Figure 2. Women as workers and caretakers. Since the 1960s women participation in the labor force has been steadily increasing, as well as the tendency to keep working during childrearing age (a). However, nowadays women keep performing the majority of housework (b).

ecosystem of behaviors as elements that participate in spatial production. Therefore, it is necessary to introduce the idea of timescale in the observation of the urban behavior of Jiyūgaoka. ${ }^{37}$ For demonstrating how changing notions of gender roles have been rendered into the urban fabric, the evolution of Jiyūgaoka's commercial contents is first investigated. The material studied is the Jiyūgaoka Shopping Association Guidebook, published yearly since 1956, as it collects all shops by content categories (Fig. 3). From the publications available by the association, one is selected to represent each decade from the 1960s until today. The total number of shops and the different categories are counted. Then, the categories that are gender-charged are listed. Gender-charged can be identified when the name itself indicates gender, for example: "women's clothing"; or when there is an existing stereotype in the Japanese context that frames that content as appropriate for a female or male subject, for example: eating sweets in Japan is considered a feminine behavior. ${ }^{38}$ The evolution of those categories is cross-referenced with the changes in gender roles over the decades.

Once it is shown that Jiyūgaoka's contents have evolved focusing on women as consumers, the second question is where it has occurred. The genderfication, the development towards a gender-charged urban fabric, can be found by mapping the female and male contents for each decade using the address that appears in the guidebook. After mapping, looking at the concentration of content, different gender-charged areas appear that 

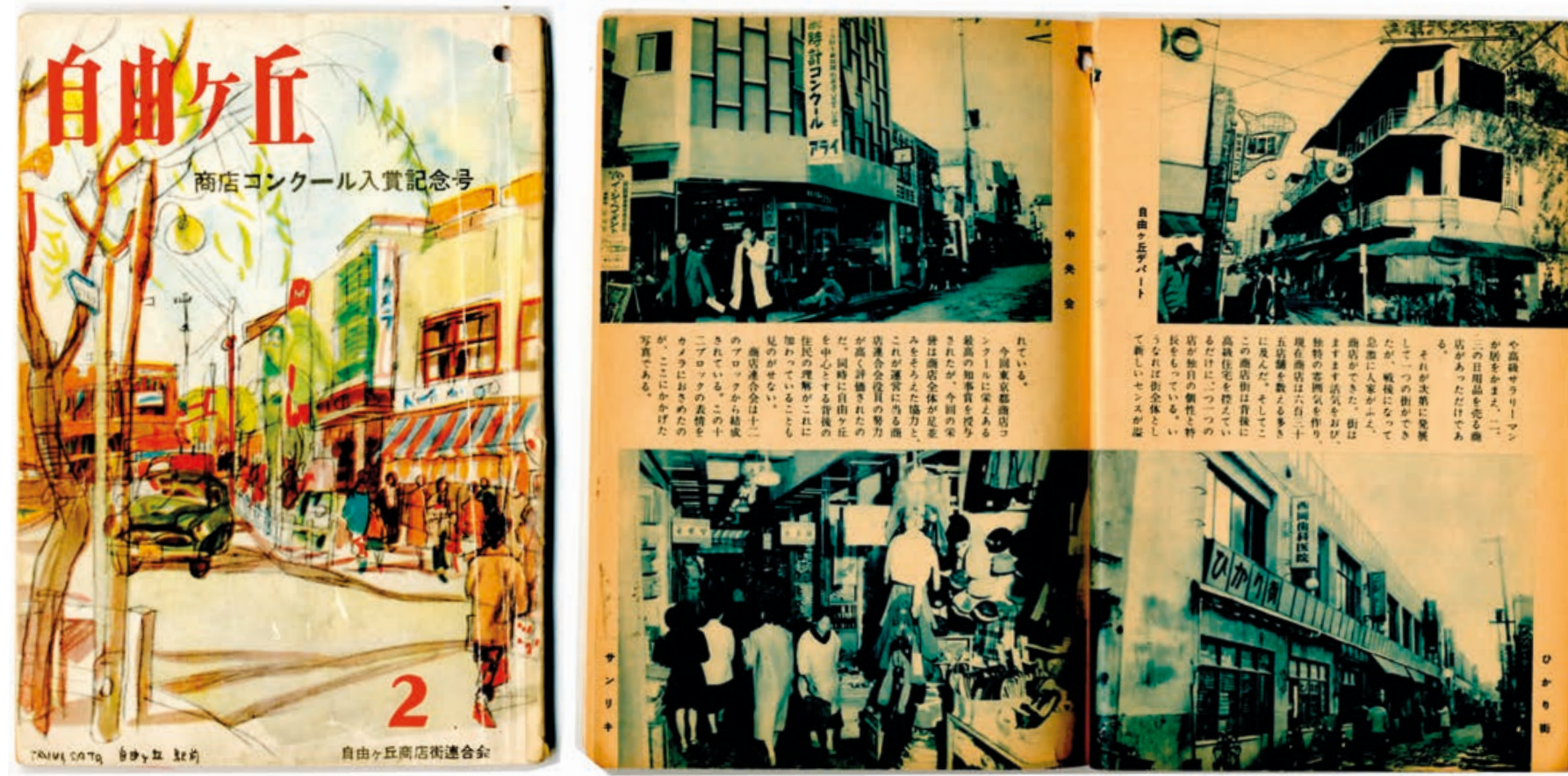

Figure 3. Jiyūgaoka Shopping Association Guidebook, vol. 2, 1958. This yearly publication, that has been recording all commercial contents since 1956, is used as comprehensive material of study.

vary over time. These areas are named according to their nearest street. This chronological investigation of the guidebook is complemented with the most representative examples to clarify the physical and social environment in which behavior occurs. The illustrations are those of critical venues of the female-charged content, accompanied by a photograph. These are drawn in axonometric view based on publications and empirical observation of strolling in Jiyūgaoka. The drawing shows together explanatory notes of the relevant environmental elements, complementing the information of the photographs. Small site maps indicate their location in Jiyūgaoka urban fabric. ${ }^{39}$

\section{CONTENTS: FROM SKILLFUL HOUSEWIFE TO YOUNG CONSUMER}

Jiyūgaoka has undergone a commercialization process reflected in the increase of shops, which has doubled from the 1960s to today (Table 1). New businesses have been continuously appearing since the 1970s. The period of most significant growth occurred in the 1980s, corresponding with the peak of economic prosperity in Japan. Jiyūgaoka's transformation was aimed at women by offering contents associated with the feminine realm in Japan. Female Charged Contents (FCC) maintained the same number of shops in the decades of the '60s and the '70s when the full-time housewife was the central character of the Tokyo suburbia. Afterward, FCC grew steeply in the '80s and '90s, when women began to enter the workforce and strengthened their capacity to spend money. Once the economic bubble 
burst, FCC remained stable, rising again in the 2010s. We can group the contents in categories that fluctuate through the decades: pedagogical services for learning housework skills and hobbies, different kinds of fashion stores from Japan and abroad, food primarily represented in sweets, interior decoration, and more recently, beauty and health.

In contrast, Male Charged Contents (MCC) present a plateau-shaped graph, growing at the same pace as the Japanese economy, slightly exceeding the FCC in the '80s, gently decreasing in the ' 90 s, to keep falling steadily after the economic recession. MCC focus primarily on the entertainment sector. Snack or Girls' bars are just two of the several formats in which men drink while chatting with the waitresses..$^{40}$ The most commonplace to drink, the izakaya or Japanese tavern, reached its maximum number in the '80s. The rise and fall of male leisure in Jiyūgaoka accompanied the general history of the salaryman. Once considered the ideal and successful work model, it came to be questioned after the economic struggle.

Table 1. Development of Gender-Charged Contents in Jiyūgaoka.

\begin{tabular}{|c|c|c|c|c|c|c|c|c|c|}
\hline \multirow{7}{*}{ 푱 } & & \multicolumn{2}{|l|}{ Contents } & \multicolumn{2}{|c|}{\begin{tabular}{l|l|}
$1960 s$ & 1970 \\
\end{tabular}} & $1980 \mathrm{~s}$ & $1990 \mathrm{~s}$ & \multirow{2}{*}{\begin{tabular}{|c|}
$2000 s$ \\
42 \\
\end{tabular}} & \multirow{2}{*}{\begin{tabular}{|c|}
$2010 \mathrm{~s}$ \\
57
\end{tabular}} \\
\hline & & \multirow[t]{3}{*}{$\mathrm{N}^{0}$ Categories } & All & 65 & 72 & 36 & 41 & & \\
\hline & & & Female & 15 & 16 & 17 & 17 & 16 & 16 \\
\hline & & & Male & 7 & 9 & 9 & 8 & 9 & 9 \\
\hline & & \multirow{3}{*}{ No Shops } & All & 643 & 721 & 1003 & 1166 & 1261 & 1294 \\
\hline & & & Female & 164 & 171 & 258 & 347 & 359 & 455 \\
\hline & & & Male & 93 & 164 & 282 & 273 & 197 & 148 \\
\hline \multirow{27}{*}{ 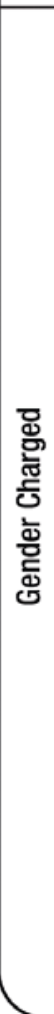 } & \multirow{17}{*}{ 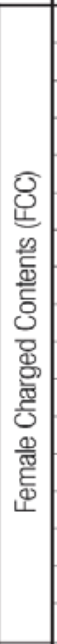 } & \multicolumn{2}{|l|}{ Schools } & 4 & 4 & 5 & 6 & 11 & 12 \\
\hline & & \multicolumn{2}{|c|}{ Flower Arrangement (ikebana) } & 8 & 5 & 4 & 5 & 7 & 9 \\
\hline & & \multicolumn{2}{|l|}{ Sewing goods } & 17 & 9 & 10 & 8 & 5 & 3 \\
\hline & & \multicolumn{2}{|l|}{ Haberdashery } & 25 & 35 & \multirow{2}{*}{105} & 31 & 31 & 49 \\
\hline & & \multicolumn{2}{|l|}{ Women Clothes } & 11 & 20 & & 142 & 94 & 91 \\
\hline & & \multicolumn{2}{|l|}{ Kids Clothes } & 2 & 5 & 6 & 6 & 14 & 16 \\
\hline & & \multicolumn{2}{|l|}{ Kimono } & 12 & 9 & 5 & 5 & 3 & 5 \\
\hline & & \multicolumn{2}{|c|}{ Accessories, Bags } & 6 & 10 & 17 & 24 & 30 & 37 \\
\hline & & \multicolumn{2}{|l|}{ Jewels } & - & 4 & 4 & 8 & 16 & 14 \\
\hline & & \multicolumn{2}{|c|}{ Decoration, Living goods } & 1 & 3 & 5 & 6 & 25 & 29 \\
\hline & & \multicolumn{2}{|c|}{ Western Sweets (yogashi) } & 1 & 1 & 5 & 9 & 6 & 16 \\
\hline & & \multicolumn{2}{|c|}{ Japanese Sweets (wagashi) } & 24 & 19 & 16 & 12 & 6 & 7 \\
\hline & & \multicolumn{2}{|l|}{ Cafe (kissa) } & 24 & 20 & 38 & 40 & 25 & 36 \\
\hline & & \multicolumn{2}{|l|}{ Beauty Salon } & - & - & 1 & 3 & 23 & 42 \\
\hline & & \multicolumn{2}{|l|}{ Cosmetics } & 10 & 11 & 12 & 15 & 19 & 31 \\
\hline & & Hairdresser & & 18 & 15 & 24 & 26 & 44 & 68 \\
\hline & & Housekeeper & & 1 & 1 & 1 & 1 & - & - \\
\hline & & Barbershop & & 13 & 11 & 6 & 7 & 7 & 10 \\
\hline & 8 & Men Clothes & & 7 & 11 & 13 & 18 & 9 & 6 \\
\hline & $\sum_{\infty}$ & Pub & & - & - & 41 & $196^{*}$ & 26 & \\
\hline & 蛋 & Snack & & - & 16 & & 196 & 53 & 48 \\
\hline & 등 & Club & & - & 4 & 138 & - & 6 & \\
\hline & 뭉 & Bar,Shot bar & & 22 & 63 & & * & 40 & 43 \\
\hline & 敢 & Cabaret & & 1 & 2 & - & - & - & - \\
\hline & $\frac{\pi}{0}$ & Drinking bar (iza & a,koryouri) & 35 & 39 & 70 & 36 & 39 & 35 \\
\hline & 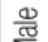 & Gaming area & & 10 & 15 & 12 & 14 & 15 & 5 \\
\hline & $\sum$ & Tobacco & & 5 & 3 & 2 & 2 & 2 & 1 \\
\hline
\end{tabular}

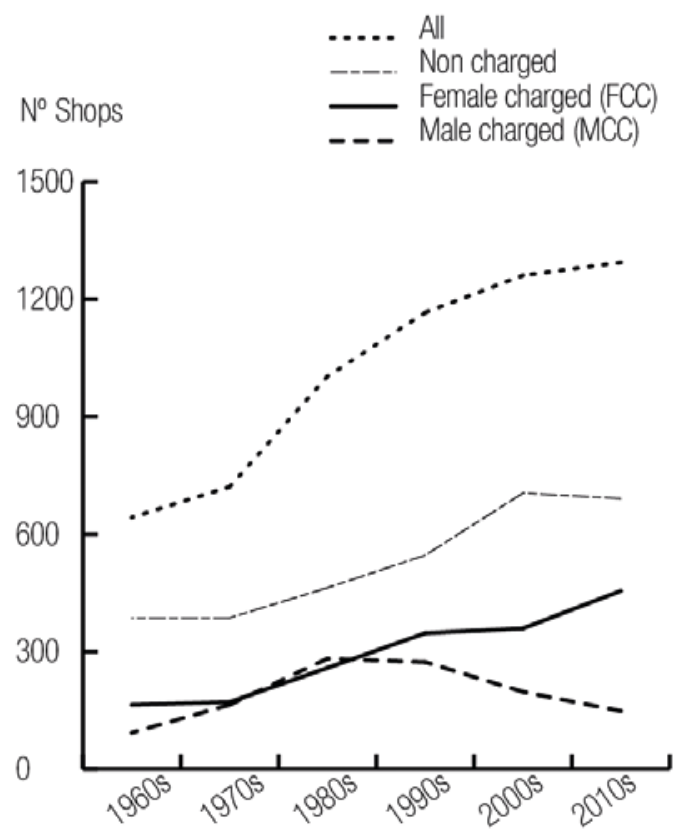

Note: Category includes for School: Cooking School, Ballet, Ikebana School, Classical Japan; for Sewing goods: Sewing machine, Material, Sewing set.: for Beauty Salon: Beauty Salon,Nail Salon, Foot Salon etc.; for Western Sweets: Western Sweets, Ice cream, Donuts; for Japanese Sweets: Japanese Sweets, Japanese Confectionery(Kanmi)Game Area: Pachinko, Mahjong.

Source: Jiyugaoka Shopping Association Guidebook (JSAG). According to the publication available, the Gender Charged Content for each decade was considered as follows: for the 1960s the 1957 JSAG, for the 1970s the 1970 JSAG, for the 1980 the 1986 JSAG, for the 1990S the 1990 JSAG, for the 2000s the 2002-2003 JSAG, for the 2010s the 2018-2019 JSAG. 


\section{The Housewife Laboratory}

A closer look at the pedagogical contents aimed at women reveals a shift from preparation for the role of housewife to a growing number of hobby-oriented classes. From learning what was considered the primary curriculum of a "professional housewife" such as sewing and cooking, it expanded to yoga gyms, glass workshops for producing tiny cute things, and tarot classes. ${ }^{41}$ Meanwhile, the traditional Japanese art of flower arrangement known as ikebana survives over time and presents about the same number of shops throughout the decades. ${ }^{42}$

The case of Gyosai Kaikan is significant as a cooking school for housewives (Fig. 4a). The three-story modernist building designed by $\mathrm{K}$. Kawashima incorporated rows of kitchens where women aligned to learn the secrets of home-cooking. ${ }^{43} \mathrm{~A}$ large auditorium and an entire floor dedicated to learning table manners were also part of the program. Built in 1950, it included separate pavilions for accommodating caring programs such as a nursery and a playground. The contents have remained in the same place since then, but the architectural envelope has changed. The latest version gained another five floors for apartments but still hosts other learning activities aimed primarily at the female sector, such as belly dance classes, crafts workshops, or singing lessons. Today, the cooking class occupies only the first floor in a protruding volume visible from the street. This symbolic building has embodied the materialization of a gender role, rendering the housewife model in the urban fabric of Jiyūgaoka.

\section{Ladies Fashionable Neighborhood}

Regarding the contents related to fashion, men's clothing reached the maximum number in the '90s with eighteen shops, with only six shops remaining at the present day, which is revealing compared to the existing ninety-one for women. In the 1960s, shops selling items to make clothes, such as sewing machines or fabrics, outnumbered the ready-to-wear. At this time, western clothing and kimono were almost equal in number. Kimono shops gradually decreased until today, remaining less than half. ${ }^{44}$ It was not until the 1980s that Western clothing skyrocketed, reaching 142 shops at their highest point in the 1990s. Inside fashion contents, small items such as accessories, bags, or jewelry have also been increasing progressively. Kids' clothing in the first decades were sold together with women's, but appeared as a separate category from the 1980s, growing remarkably in the last decade.

All these changes reflected once again the shift in women's roles, from a skilled housewife who made the clothing for the whole family to a young consumer interested in fashion, who does not produce but buys imported clothes in her favorite boutiques. This aspect, together with a wave in women's magazines featuring Jiyūgaoka as "fashion town for ladies," 
enticed female pop idols to open their stores in this "stylish city" (oshare machi). A representative case is that of Seiko Matsuda, one of Japan's best-known idol singers, who opened her fashion store "Flawless Seiko" in 1988 in Jiyūgaoka (Fig. 4b). This new milestone was trendy among Tokyo girls. That a star as famous as Seiko Matsuda selected Jiyūgaoka, marked its reputation and atmosphere, focusing on young wives. ${ }^{45}$

\section{The Interior Decoration Shop That Triggered Street Pavement}

Interior decoration and home product shops have increased since the 1990s. This niche aimed at women emerged in 1982, when the famous interior decoration magazine "My room" (Watashi no heya), opened its headquarters dedicated to household items in Jiyūgaoka. ${ }^{46}$ Very popular among housewives, it introduced an original type of store in the neighborhood (Fig. 5). The design novelty relied on the combination of a setback ground floor, a big glass shopping window, and a continuous pavement that dissolved the boundaries between inside and outside.

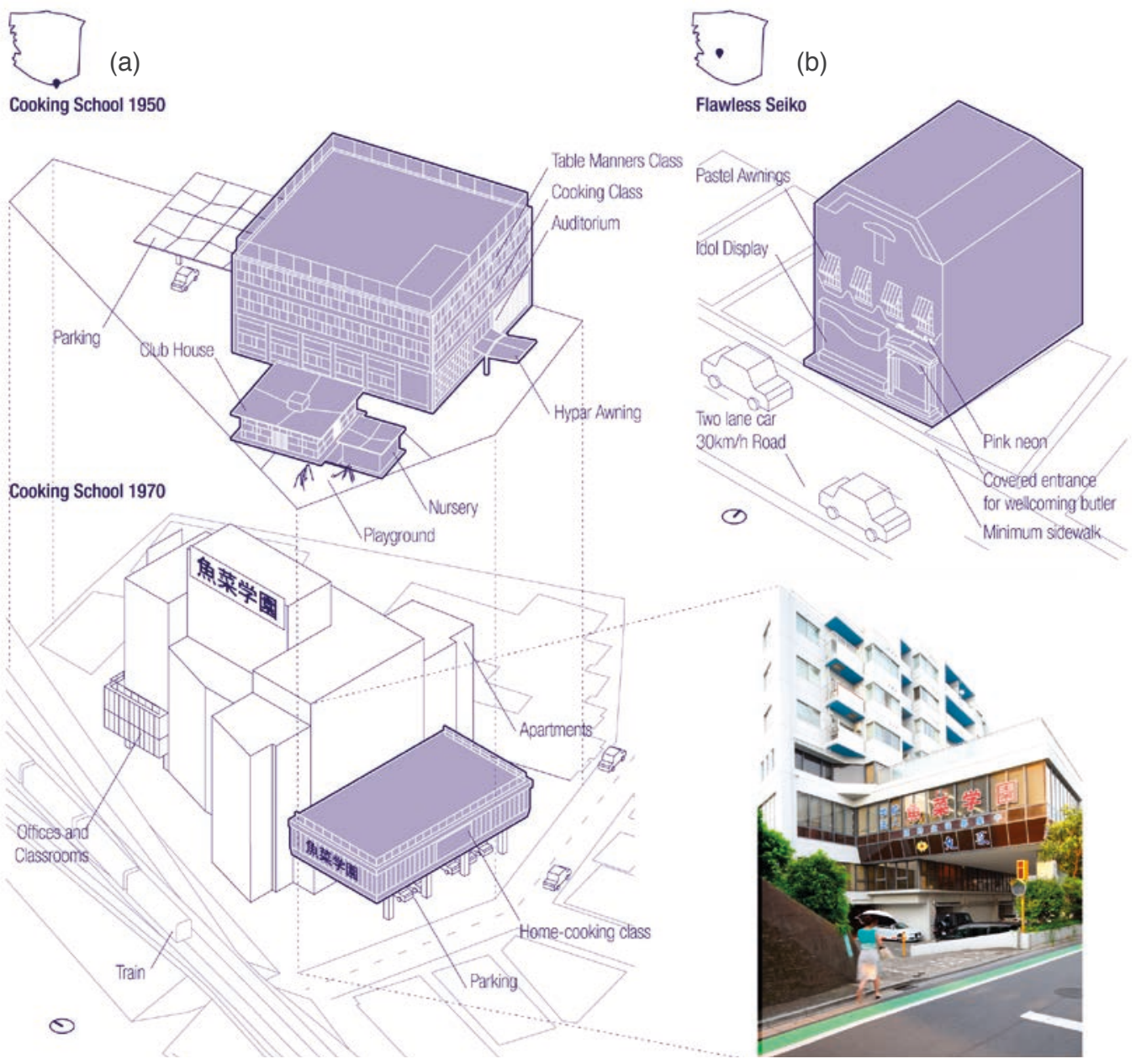

Figure 4. Home Cooking School in the 1950s expanded into a women-oriented Learning Center in the 1970s (a) and Flawless Seiko as the emergence of pop idol fashion boutiques in the late $1980 \mathrm{~s}(\mathrm{~b})$. 
Watashi no heya is a case in which the existence of a single building has an important influence on the quality of collective space. The town management organization in Jiyūgaoka followed this example to create city guidelines. The cluster of streets around Watashi no heya, renamed as "Sunset Area" in 2003, was paved with porphyry stone and benches in front of the shops. In the approved urban planning, it is stated:

In order to create a comfortable and safe commercial environment mainly for women and families, continuous walking space and barrier-free measurements are encouraged. Also, the following uses are prohibited in the area: parking lots, cabaret, night club, game centers, pachinko, or sexual services. ${ }^{47}$

\section{A Sweets Town for Young Girls and the Beauty Boom}

After the economic recession of the 1990s, Jiyūgaoka still continued to congregate sophisticated clothing boutiques, but its most prominent

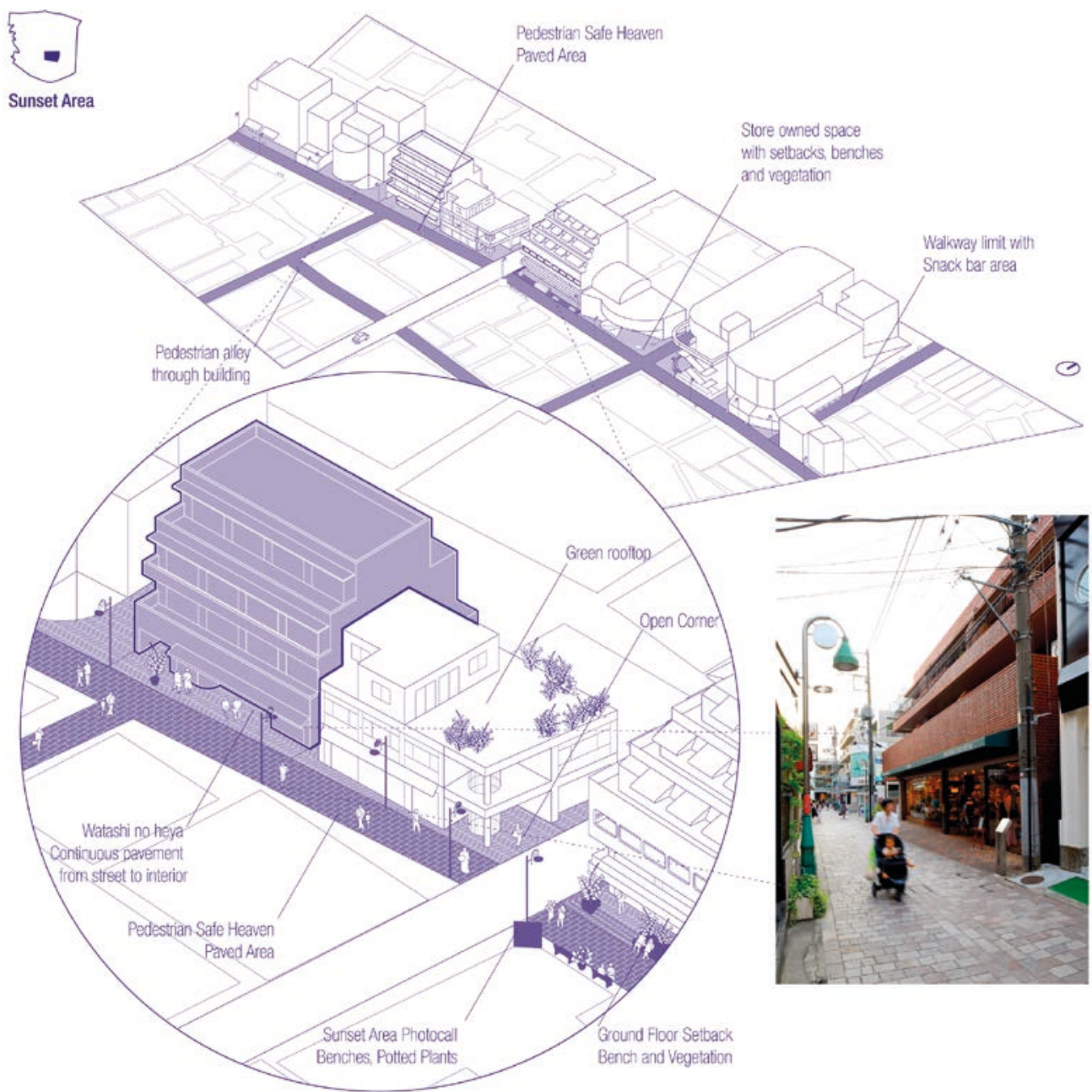

Figure 5. Interior design magazine Watashi no Heya headquarters, built in 1982. The shop innovative design in relation with the public space was used as model for pedestrianization of the surrounding "Sunset Area." 
image is related to sweets. ${ }^{48}$ This branding change from fashion to "the city of sweets" is based on enhancing Jiyūgaoka coffee shops (kissa). These spaces, which are associated with the female sphere in Japan, ${ }^{49}$ have maintained a constant number throughout the decades. "Mont Blanc" and "Sweets Forest" are notable examples of this type of content. Mont Blanc is a pioneer confectionery store founded in the '50s that earned its reputation as one of the best in Tokyo. Sweets Forest, built in 2003, is the first building in Japan specialized only in sweets. Apart from housing a dozen sweets shops, it encloses a cooking-ware shop, confectionary cooking classes, and has exported a flagship store right next to the station. Following the theme park model, it uses the imaginary of sweets in order to attract the youngest female population group. ${ }^{50}$ Since the 1980s, services related to female beauty have increased in Jiyūgaoka. Before that, only hairdressers (biyōshi) specialized exclusively in the female sector, and men used to cut their hair in the barbershop. While barbershop numbers have remained constant over the years, biyōshi have grown to be almost four times more than in the '60s. The concept of "beauty salon," as a specialized place for aesthetic treatments related to the skin, eyelashes or nails, did not appear until the 1990 s and has increased steadily in the 2010s.

\section{GENDER-CHARGED AREAS: FROM SPONTANEOUS CONCENTRATION TO CITY GUIDELINES}

After studying Jiyūgaoka's content and verifying that indeed it has undergone a process of genderfication aimed at women, a question arises: How does the gender-charged content operate at its intersection with the urban fabric? The contents discussed in the previous section are mapped for answering what their physical translation in the city is (Table 2). After mapping, gender-charged areas appear, in which the content concentration varies over time. Male-charged areas (MCA) have developed isolated from each other. And even though they have persisted in the same locations across decades, their concentration has decreased significantly from the '80s. Some of them have even disappeared or turned into female-charged areas (FCA). Meanwhile, female charged content is intertwined and blended with the mass of single-family houses. FCA have progressively expanded throughout the urban fabric through the decades, presenting different concentrations but always growing and never disappearing. In the following sections, these changes are explained chronologically, developing the relevant cases of each period.

\section{0s Jiyūgaoka Depato: A Bottom-Up Department Store}

In the 1960s maps, both female and male contents are spread on the north side of the station. Only one dot appears in the very south (Kuhonbutsu Area): the cooking school for homemakers. Two areas present the highest concentration: Yorimichi Yokocho, a cluster of men-oriented services, and 
Table 2. Development of Gender-Charged Areas in Jiyūgaoka.

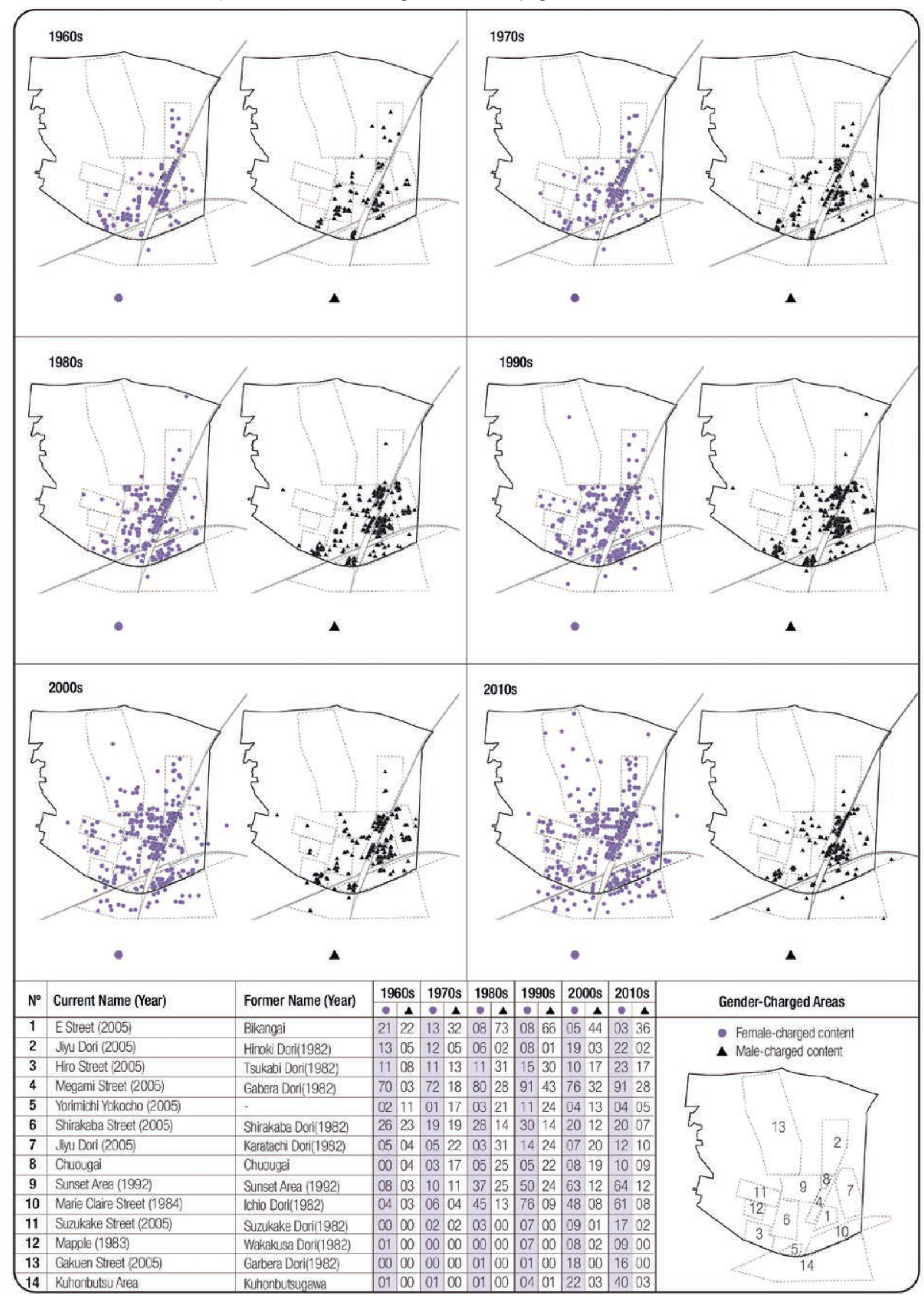


Megami Street, with a high density of women-oriented shops. The 1960s Yoromichi Yokocho is an isolated triangle, shaped by the limits of the rail tracks, the train parking, and the Kuhonbutsu river. ${ }^{51}$ It is composed of tiny buildings of two stories, about $2.5 \mathrm{~m}$ [8 ft. 2 in.] width and $5 \mathrm{~m}$ [16 ft. 4 in.] depth, arranged in dark and narrow alleys. In the 1970s, this urban island type proliferated, and four more areas consolidated in the same kind of cramped fabric: Jiyū Dori, Hiro, Chuogai, and Bikangai. In the Jiyū Dori area, small-scale constructions sheltered snack bars. The dense L-shape fabric of Hiro area enclosed a showa-style cabaret named Dream Paradise (Yume no paradaisu) that still survives as a bar. In the Chuogai area, MCC is also packed in a residual shape that results from the intersection of traffic roads and rail tracks. Analogous conditions engendered Bikangai, another male entertainment fabric famous for drinking places such as Kaneda Sake School. ${ }^{52}$

From the 1960s, women-oriented shops gather longitudinally in Megami Street (Goddess Street) in the north-west of the station. The agglomeration happens mainly inside three buildings: Jiyūgaoka Depato, Hikarie, and Sanriki. These evolved from post-war shopping streets located on the same sites where they stand today. About a hundred merchants arranged their wooden barracks following the Tokyu-Toyoko train tracks shortly after the war. In 1955, without help or approval from the government, the shop tenders joined forces and decided to transform the black market street by themselves, resulting in the long and narrow shaped buildings. ${ }^{53}$

Although dating from the fifties, Jiyūgaoka Depato is still a bustling department store. With women-oriented inner shopping arcade on the ground floor, an open gallery of ethnic restaurants on the first floor, and closed snack bars for men on the third floor (Fig. 6). The gender strata vary in section from FCC to MCC, relating not only with the position in space but with time use. ${ }^{54}$ The FCC opens during the day, the restaurants' floor runs from lunch to dinner time, and the MCC operates only during the night. The spatial configuration in which the stacking of floors corresponds to a gender stratification of contents, and its creation from a bottom-up movement, makes it a unique gender-charged typology.

1980s Marie Claire: Urban Revitalization Inspired by a French Magazine

In the 1980s, MCC continued densifying in the same areas where it had already appeared in previous decades. Regarding FCC, the Megami area kept the hyper concentration of women-oriented shops. However, it expanded further into other regions that lit up as new women's territory, such as Sunset Area and Marie Claire Street. The south exit of the station used to have a completely different character from the north side. It was predominantly residential, with few entertainment facilities such as love hotels or drinking places. Merchants and residents decided to revitalize their area using the media as a driving force, a similar approach as their northern neighbors of Sunset Area. Women's magazines that arose in 


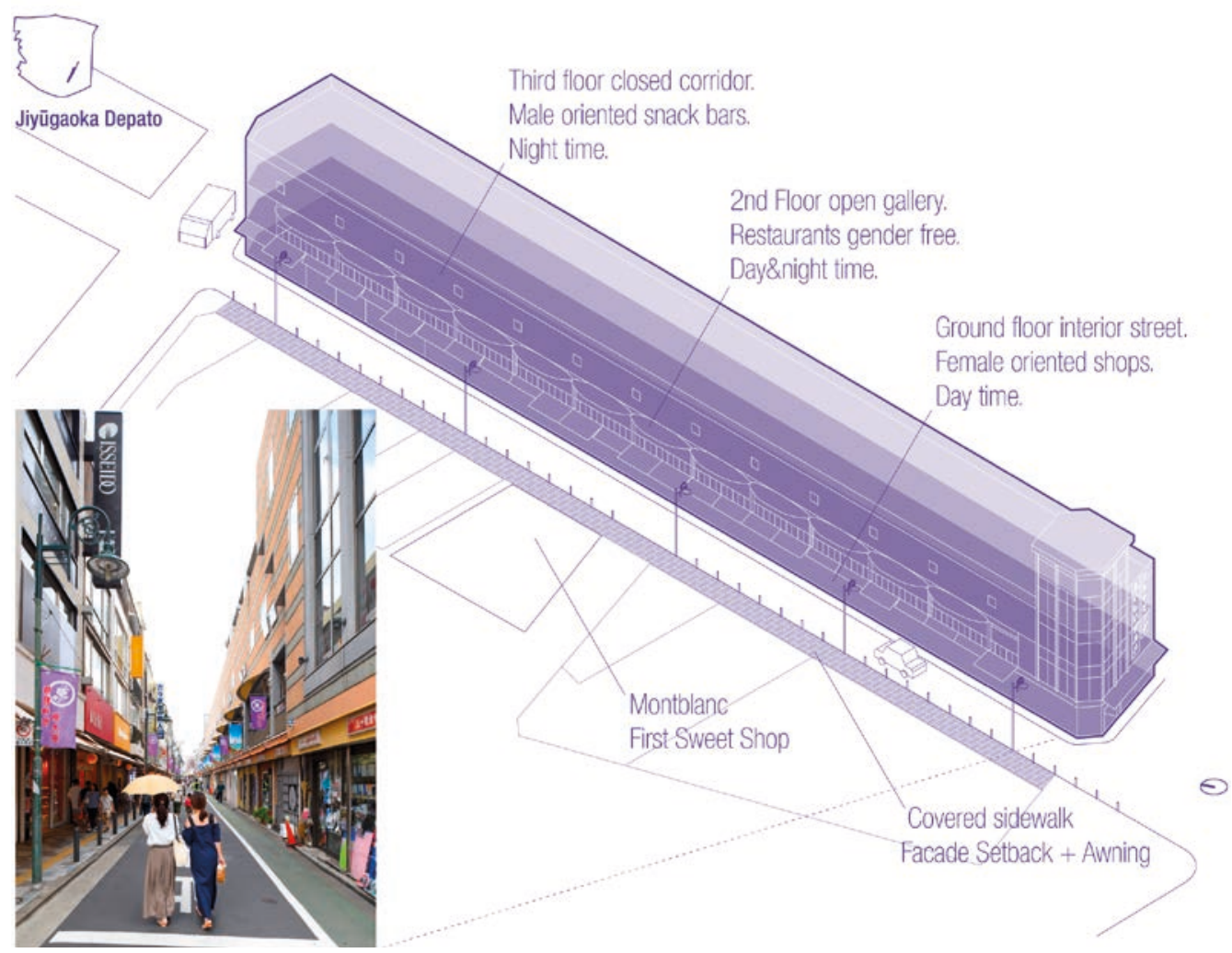

Figure 6. "Jiyūgaoka Depāto", gender-charged content stacking from the 1950s. This long and narrow building was developed by the joint effort of all the previous small shops following the train tracks.

the 1970s, and whose target profile was young women, were massively published introducing Jiyūgaoka as a "town where fashionable shops gather." ${ }^{55}$ In 1984 the previous Ichio Dori was renamed after the newly launched Japanese version of the French magazine Marie Claire. ${ }^{56}$ Mr. Watanabe, the president of the South Shopping Association at that time, declared: "The name Marie Claire Street intends to create a city that would attract the type of Marie Claire magazine readers." ${ }^{57}$ The urban development to achieve the goal of "Women's town: Marie Claire Street" (Joseirashī machi: Marikurēru-dōri) started from the elimination of electric poles, ubiquitous to Tokyo scenery. Besides the undergrounding of the cables, the design measures that followed through the years included customized street lights, security cameras, cobblestone pavement, and the designation of a barrier-free zone ${ }^{58}$ (Fig. 7).

\section{0s Kuhonbutsu Promenade: An Inclusive Public Space}

After the rebranding of the area, in the 1990s, Marie Claire street experienced the maximum concentration of FCC. ${ }^{59}$ Also, Megami and Shirakaba areas reached their peak in women-oriented shops. In contrast, the MCC revealed a dropping tendency in areas such as Bikangai, Hiro, or Chuogai. After the economic crisis, male entertainment businesses abruptly reduced in all of Jiyūgaoka. MCC almost disappeared from once- 
bustling areas such as Yorimichi Yokocho, which were reduced to just a few snack bars. In this decade, a new type of women-oriented concentration appeared in the living area farther from the station, where the consolidated commercial fabric did not exist. Although this latest formation occurred in large plots, it adopted a scale similar to the residential fabric, by dividing the land into several buildings and creating a semi-public space in between. The most striking case is that of "La Vitta," which took the theme park strategy to the extreme, creating a micro canal with a gondola. Sunset Area, the Watashi no heya domain, grew in women-oriented shops since the '80s while keeping male-oriented services. From the 2000s, the Sunset Area aimed at women exclusively, enforcing city design guidelines that banned nighttime uses. The last decade of the 2010s is when the genderfication towards women culminated. The female contents strengthened their presence in Hiro and Shirakaba areas. Also, women shops proliferated among the detached houses in Gakuen Street. However, the area where FCC germinates more vigorously than ever is the Kuhonbutsu area (Fig. 8).

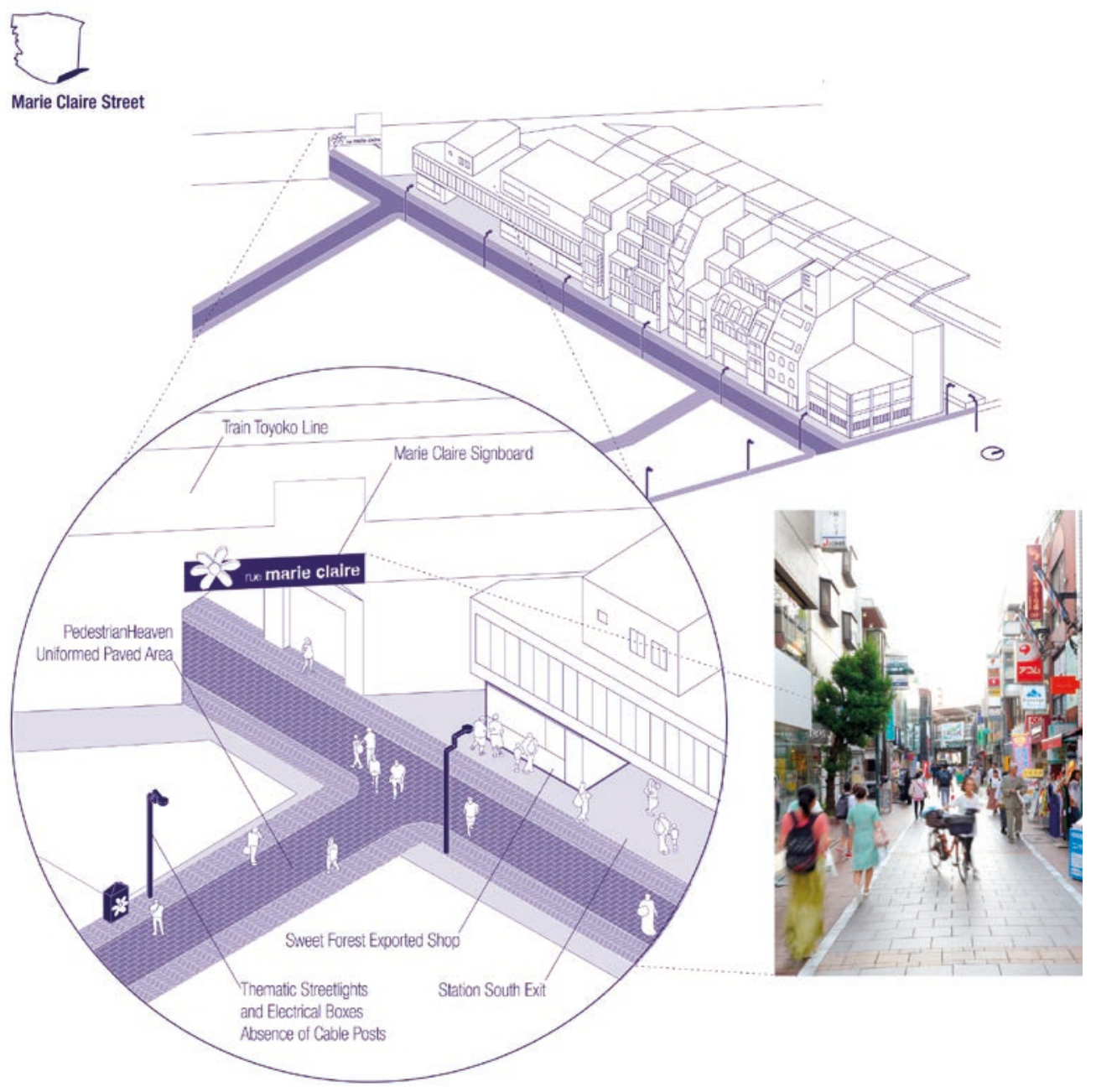

Figure 7. Marie Claire Street, named in 1984. This urban development aimed to create an environment that would attract the type of female readers of the French magazine Marie Claire, which launched its Japanese edition in 1982. 
Under the Kuhonbutsu promenade flows a river where children used to play, and that was covered in 1974 due to pollution. In 1994, residents and merchants improved the environmental status of the area with street lights and pavement, expanding the female realm of Marie Claire street. Sweets Forest, the theme-park building for sweets, opened in 2003, acting like a magnet on the eastern side of Kuhonbutsu. The numerous bicycles that were parked at the green promenade became a problem for the city maintenance. Again, as a bottom-up strategy, local commerce and residents placed hundreds of benches and flower planters to avoid the accumulation of bikes that hindered walkability. ${ }^{60}$ The measure that designated the area as illegal for parking was complemented with the construction of a bicycle parking lot. This infrastructure is part of Trainchi, a shopping complex built in 2006 on the grounds of the train depot.

The town management organization became aware that not only shops but also the street design were vital in making Jiyūgaoka a "fashionable town"

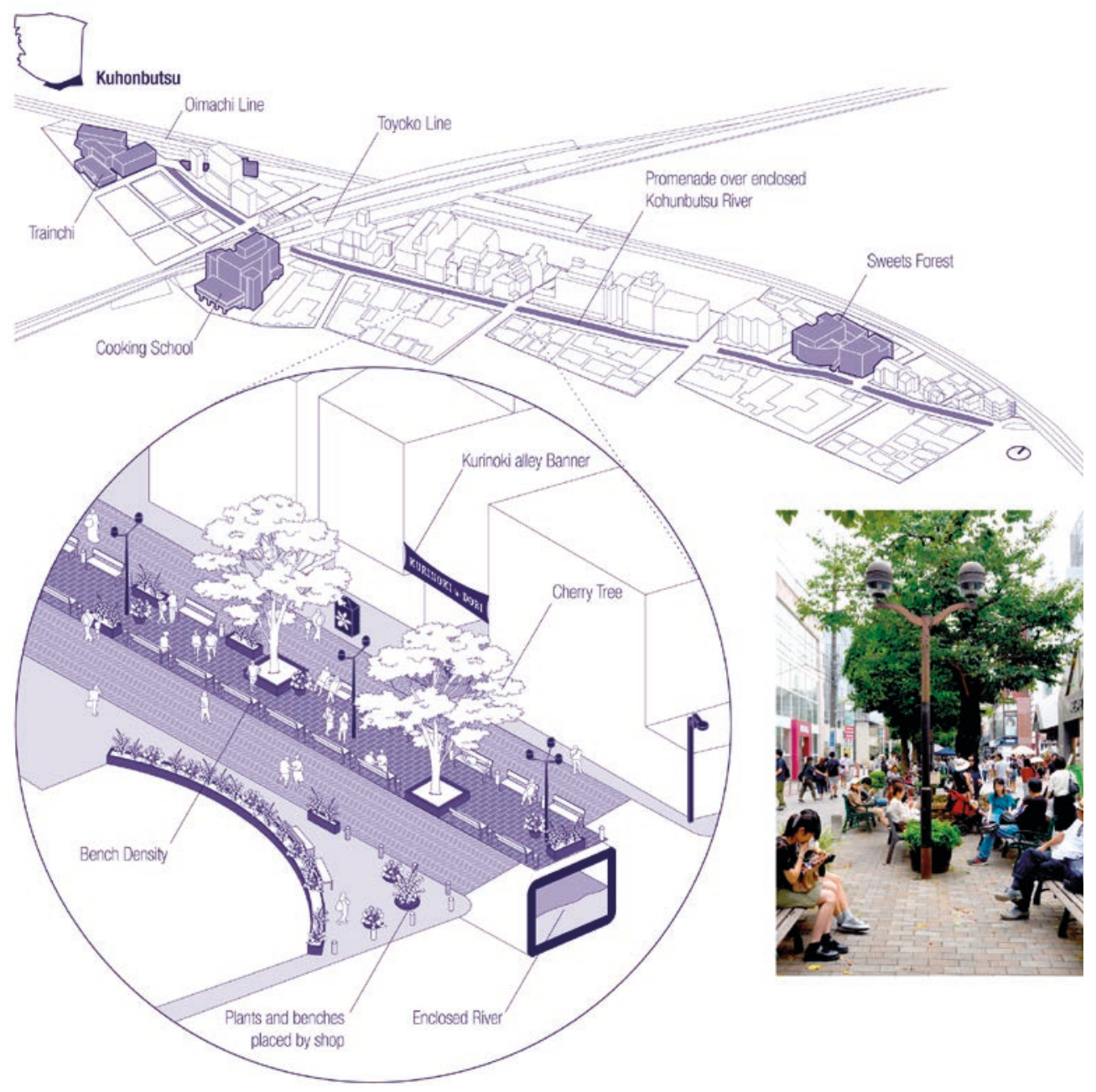

Figure 8. The Kuhonbutsu river was enclosed in 1974. Since then, a series of bottom-up urban transformations undertaken by the commercial association together with the residents have resulted in a lively public space for diverse and intergenerational behaviors. 
and in 2009 created the Jiyūgaoka cityscape guidelines. ${ }^{61}$ For the formation of the urban rules, residents, landowners, shopping associations, and train companies collaborated with urban planners. ${ }^{62}$ The government made this plan official in 2016, aiming at a "comfortable walking environment." The urban plan formulated pedestrian spaces, setbacks, improvement of street pavement, and the creation of a barrier-free zone. Also, the regulations indicate some use restrictions such as gaming areas or adult entertainment bars. ${ }^{63}$

The subsequent growth of the south area combined bottom-up energies, better known in Japanese as machi-zukkuri (town-making), with an intensification of female charged contents. The eleven meters wide promenade has translated all these forces into physical space, mixing hundreds of benches, greenery, fashion, and sweet shops. By providing places to rest under the shadow of cherry trees, other bodies besides women were registered into the city. Today, different behaviors can be seen in Kuhonbutsu: an older man taking a nap, teenagers chatting after school, or parents watching their children play. ${ }^{64}$ The enhancement of pedestrian streets resulted in a democratization of urban space that emerged from aiming at women as primary users.

\section{CONCLUSION: GENDERFICATION AIMING AT WOMEN THAT ENHANCED URBAN LIFE}

This study demonstrated how Jiyūgaoka, a wealthy Tokyo suburban neighborhood, has undergone a genderfication process with women as the target group. For investigating such phenomena, this article looked at the historical development of gender-charged contents, its concentration in the city, and its physical translation in urban space. Analyzing the Jiyūgaoka Shopping Association Guidebook from the 1960s until today, it was found that the types of female-charged contents have diversified through the decades. From the 1980s, the commercial contents focusing on basic needs related to housekeeping were expanded to incorporate new lifestyles. This shift encompassed changing notions of women's roles in Japanese society, adding to the existing profile of the "housewife," the young student, or the working woman. While female-charged contents (FCC) have grown over time, the male-charged contents (MCC) significantly declined in recent decades. The chronological mapping of the gender charged contents revealed how Jiyūgaoka's genderfication has been occurring in different locations and gradually over time. While FCC has expanded in the residential fabric, MCC has remained in the same areas, changing only the intensity of concentration. Representative examples of female-charged areas illustrate the physical translation of genderfication in the urban fabric: Jiyūgaoka Depato as an emblematic typology of the 1960s, Marie Claire Street as characteristic of the 1980s, and Kuhonbutsu Promenade of the 2010s. 
Jiyūgaoka's genderfication development has an ambivalent nature for intertwining bottom-up measures from residents and local shop owners while focusing on women as consumers. Jiyūgaoka case study continues problematizing the intersection of gender and gentrification, in a scarcely explored non-western context like Japan. Until now, this process prevails as a success story by keeping the city character with high urban quality. However, this study also wants to raise awareness that an excess of commercialization can turn the city into a conventional open mall and, therefore, decrease the range of behaviors not linked to profitable uses. Also, corseting women in their role as consumers presupposes the only existence of a middle-high class and neglects other economically challenged social groups. Despite this risk of city marketization towards a gender-charged niche, the diversity of scales, the unique character of each area, and the rooted urban solutions that address women with their design, make Jiyūgaoka a remarkable example. By including women as primary users, the public realm was diversified, acknowledging other bodies besides the normative, like children, the elderly or the physically challenged. Tokyo's public sphere, which usually functions as a transitional space towards productive work, is transgressed here to be a place where caregiving activities occur. In Jiyūgaoka's case, the urban transformation towards women has resulted in better environmental quality, enhancing accessibility, urban mobility, and street life.

\section{Notes}

1. Koyama Shizuko and Gabriel A.Sylvain, "The 'Good Wife and Wise Mother' Ideology in Post-World War I Japan," U.S.-Japan Women's Journal no. 7 (1994): 31-52.

2. Anne Harris, and Stacy Holman Jones, "Genderfication," in Critical Concepts in Queer Studies and Education, eds. Nelson M. Rodriguez, Wayne J. Martino, Jennifer C. Ingrey, Edward Brockenbrough (New York: Palgrave Macmillan, 2016), 117-26.

3. Marguerite van den Berg, "The Discursive Uses of Jane Jacobs for the Genderfying City: Understanding the Productions of Space for Post-Fordist Gender Notions," Urban Studies 55, no. 4 (2018): 751-66.

4. Daphne Spain, Gendered Spaces (Chapel Hill NC, USA: University of North Carolina Press, 1992).

5. Daphne Spain, "Gender and Urban Space," Annual Review of Sociology no. 40 (2014): 581-98.

6. Yoshiharu Tsukamoto and Momoyo Kaijima, Atelier Bow-Wow: Behaviorology (New York: Rizzoli, 2010).

7. See for example Liz Bondi, "Gender Divisions and Gentrification: A Critique," Transactions of the Institute of British Geographers 16, no. 2 (1991): 190-98; Beatriz Colomina and Jennifer Bloomer, Sexuality and Space (Princeton NJ, USA: Princeton Architectural Press, 1992); Dolores Hayden, "What Would a Non-Sexist City Be Like? Speculations on Housing, Urban Design, and Human Work," Signs 5, no. 3, supplement "Women and the American City" (1980): 170-87; Gerda R. Wekerle, "Women in the Urban Environment," Signs 5, no. 3: 188-214.

8. Henri Lefebvre, The Production of Space, trans. Donald Nicholson-Smith (Oxford, UK: Blackwell, 1991); or. ed., La production de l'espace (Paris: Anthropos, 1974).

9. Doreen Massey, Space, Place and Gender (Minneapolis MN, USA: University of Minessota Press, 1994).

10. Zaida Muxí, "Urbanismo moderno: mujeres públicas versus la mujer privada" in Mujeres, Casas y Ciudades: Más allá del umbral (Barcelona: dpr-barcelona, 2018): 277-317. 
11. Elisabeth Wilson, The Sphinx in the City: Urban Life, the Control of Disorder, and Women (Berkeley CA, USA: University of California Press, 1991).

12. Petra L. Doan, ed., Queerying Planning: Challenging Heteronormative Assumptions and Reframing Planning Practice (Farnham, UK: Ashgate, 2011).

13. Chizuko Ueno, The Modern Family in Japan: Its Rise and Fall (Balwyn, North Victoria, Australia: Trans Pacific Press, 2009).

14. Noemí Gómez Lobo et al., "Social Ecosystem of architectural design in the discourse of women architects in Japan," AlJ Journal of Technology and Design 25, no. 61, (2019): 1385-90, https://doi.org/10.3130/aijt.25.1385

15. Emiko Ochiai, The Japanese Family System in Transition. A Sociological Analysis of Family Change in Postwar Japan (Tokyo: Yuhikaku Publishing Co.,1994), 32.

16. Suzanne Hall Vogel and Steven K. Vogel, The Japanese Family in Transition: From the Professional Housewife Ideal to the Dilemmas of Choice (Lanham MD, USA: Rowman \& Littlefield Publishers, 2013), kindle.

17. Ofra Goldstein-Gidoni, Housewives of Japan. An Ethnography of Real Lives and Consumerized Domesticity (New York: Palgrave Macmillian US, 2012).

18. Junichiro Okata and Akito Murayama, "Tokyo's Urban Growth, Urban Form and Sustainability," in Megacities. Urban form, Governance, and Sustainability, eds. Andre Sorensen and Junichiro Okata (New York: Springer, 2011), 15-41.

19. Koh Kitayama, Yoshiharu Tsukamoto and Ryue Nishizawa, Tokyo Metabolizing (Tokyo: Toto, 2010).

20. Robin M. Le Blanc discusses in Bicycle Citizens: The Political World of the Japanese Housewife (Berkeley CA, USA: University of California Press, 1999).

21. Zaida Muxí, "Criterios para la inclusión de la perspectiva de género en el urbanismo," in Perspectivas de género en la arquitectura, ed. Lucía C. Pérez-Moreno (Madrid: Abada Editores, S.L., 2018), 81-103.

22. "Open Market, Jiyugaoka Station," accessed July 29, 2019, https://market.openrm.jp/ prefectures/toukyouto/stations/

23. Complete report in Japanese: http://www.mlit.go.jp/report/press/toshi10_hh_000107.html 24. The history of this area is written in the Kuriyama family document, "Kuriyama Kyujirou Ouryakude."

25. Jiyūgaoka Official Guide 2018-2019, vol. 29 (Tokyo: Shōbunsha, 2018).

26. Jiyūgaoka no okurimono watashi no o-ten, watashi no machi (Tokyo: Mishima-sha, 2013).

27. In 1961 the goddess statue was placed in the newly built station square. From that moment, the symbol of Jiyūgaoka is the sculpture of a naked woman with enormous wings. 28. Takeda Shiguetarō, Jiyūgaoka Fujin (Tokyo: Kōbunsha, 1960).

29. Around 1955, when the reconstruction was in full swing, Jiyūgaoka had six movie theaters. However, after television became more popular since the 1970 s, cinemas began to disappear. The last one was transformed into a kindergarten in 2004.

30. Hanako zoku (Hanako tribe) was the buzzword used to describe the 1980 s new type of woman, who married later, had new consumption habits, better education, and more freedom than previous generations. For an insight of women magazines in Japan, see Dolores Martínez, ed., The Worlds of Japanese Popular Culture. Gender, Shifting and Global Cultures (New York: Cambridge University Press,1998) and Atsuhi Naruse, "The Guide of Tokyo Living: Geographic Representation in the Weekly Magazine of Women," Quarterly Journal of Geography, no. 52 (2000): 180-90.

31. "Proportion of married by the ages 45-59 and 50-54," National Institute of Population and Social Security Research, accessed July 12, 2019, http://www.ipss.go.jp/site-ad/index english/Survey-e.asp

32. "Employment Pattern by Gender and Age 2017," Statistics Year Book of Japan (Tokyo: Statistics Bureau, Ministry of International Affairs and Communications, 2018).

33. "White paper on gender equality," Gender Equality Bureau, Cabinet Office, Government of Japan (2019).

34. Yoko Watanabe, "Why is the gender gap in time spent on housework still so wide? From the 2015 NHK Japanese time use survey" (2017), http://www.nhk.or.jp/bunken/research/ yoron/pdf/20161201_6.pdf 35. Ueno, The Modern Family in Japan. 36. Ibid. 
37. For other example of chronological urban mapping see Yoshiharu Tsukamoto and Momoyo Kaijima, "Walking with Atelier Bow-Wow: Kanazawa Machiya Metabolism," in Atelier Bow-Wow: 338-39.

38. Men who engage in "typically feminine acts, such as cooking and eating sweets" are nicknamed "herbivorous boys" in Japan. See Keichi Kumagai, "Floating Young Men: Globalization and the Crisis of Masculinity in Japan," HAGAR Studies in Culture, Policy and Identities, no. 10 (2012): 3-15.

39. For other example of drawing and photographing as research methodology see Momoyo Kaijima, Junzo Kuroda and Yoshiharu Tsukamoto, Made in Tokyo (Tokyo: Kajima Publishing, 2001).

40. In the snack bar, the proprietress is called "Mama" according to the Japanese custom. Chizuko Ueno argues that men create "pseudo-families" by singing karaoke and drinking together.

41. In Japan, the fortune-telling service is known as uranaishi, and their customers are primarily women consulting romance-related issues. See Philip Brasor and Masako Tsubuku, "Putting the 'Fortune' Back in Fortune Telling," The Japan Times (March 18, 2012). 42. After the 1960s, there was an increase in women participation in traditional activities such as dance, tea ceremony (chanoyu), and ikebana. See Nancy Stalker, "Flower Empowerment. Rethinking Japan's Traditional Arts as Women's Labor," in Julia C. Bullock et al., eds., Rethinking Japanese Feminisms (Honolulu HI, USA: University of Hawaii Press, 2018): 103-08.

43. "Jiyūgaoka Cooking School by K. Kawashima, Architect and Associates," Kenchiku Bunka, 12 (1954):13-20.

44. Traditionally, women were responsible for making clothes. Kimonos were one of the most precious female heritage. See Jordan Sand, House and Home in Modern Japan. Architecture, Domestic Space and Bourgeois Culture, 1880-1930 (Cambridge MA, USA: Harvard University Asia Center, 2005).

45. "Enjoy Jiyugaoka," Jiyugaoka Commerce Promotion Committee, no. 3 (1988): 21. 46. See Watashinoheya 45 syuunen tokubetsu. https://www.watashinoheya.co.jp/02_ syohin/45th_2.html

47. "Chapter 3. Article 10: Use-related matters" in Jiyugaoka Sunset Area Machizzukuri Agreement, J-Spirit. Available at: https://www.jiyugaoka-spirit.com/Street_formation/pdf/ Sunset_development_agreement.pdf

48. See Mari Ako, Jiyugaoka Sweets Story (Jiyūgaoka suītsu monogatarı) (Tokyo: NTT Publishing, 2011), and "Nice Sweets Time" (sutekina suitsu jikan) in Hanako Cityguide, Magazine House Mook (2018): 67-68.

49. Haruko Doi, "Survey on changes in confectionery and desserts that are closely related to daily life," Management and marketing department, Research Institute of Japan Management Association, 2017, http://www.jmar.biz/report/life/17_snack.html 50. At first, it was thought as "Sweets Factory", but after reconsidering "factory" as "masculine," it was changed to "forest." See Kazuya Okada and Mari Ako, Jiyūgaoka burando - Jiyūgaoka shōten-gai no chōsen-shi (Tokyo: Sanno University Publishing, 2016). 51. Tatsuya Okabe, "Jiyugaoka machizukuri," Sanno University Report no.11 (March, 2008). 52. Intellectuals used to gather in this place since 1936. See "Otona no tame no sake gakkō," Jiyugaoka Official Guide 2018-2019, no. 29: 35.

53. "Jiyugaoka no okurimono" (Mishimasha, 2013): 60-65

54. This configuration is the reverse version of the department type in western contexts, where men services are situated on the first floor. See Dörte Kuhlmann, Gender Studies in Architecture. Space, Power and Difference (Abingdon, UK: Routledge, 2014): 193. 55. "Zasshi jōhō de hito ga atsumaru jidai," in Jiyugaoka shopping district association $50^{\text {th }}$ anniversary magazine 1963-2013 (October, 2013): 92-93.

56. This propaganda act triggered the bond with foreign cities. To the French-Japanese relation, the Shopping Association summed a partnership with New York's Madison Avenue in 1987.

57. Okada and Ako, Jiyūgaoka burando.

58. "Jiyūgaoka Minamiguchi chiku-gai-dzukuri kyōtei," https://www.city.meguro.tokyo.jp/ kurashi/sumai/katsudo/chiku_kenchiku/chikukeikaku/minami.html

59. In 1993 Marie Claire Festival started two decades after the most popular event in Jiyūgaoka, Megami Matsuri (Goddess Festival). See Yuko Uchino, "A Study on Local Events and Their Effect on Attracting People," Meiji Gakuin University Faculty of Economics, 2006. 
60. See "Kuhonbutsugawa street," Urban Acupuncture Database, accessed August, 2019, http://www.hilife.or.jp/cities/?p=979

61. Jiyugaoka Cityscape Guidelines. J-spirit, 2019, http://www.jiyugaoka-spirit.com/Street_ formation/living.html

62. Erina Kondo, "Community Based Town Development Using TMO. A Case Study on Jiyugaoka area," Waseda University, Faculty of Cultural Design, 2013, http://www.waseda.jp/ sem-muranolt01/SR/S2013/S2013-kondou.pdf

63. "Jiyugaoka south exit district city planning," Meguro ward, 2016, https://www.city.meguro. tokyo.jp/kurashi/sumai/katsudo/chiku_kenchiku/chikukeikaku/minami.html.

64. See Darko Radović, "The street and Democracy, Japanese style. Several Glimpses into the Processes of Making and Living Kuhonbutsugawa Ryokudo," (2016) and "The roles of Gentrification in Creation of Diverse Urbanities of Tokyo," Open House International, 35 (2010): 20-28.

\section{References}

Bondi, Liz. "Gender Divisions and Gentrification: A Critique." Transactions of the Institute of British Geographers 16, no. 2 (1991): 190-98.

Lefebvre, Henri. The Production of Space. Translated by Donald Nicholson-Smith. Oxford, UK: Blackwell, 1991. Or. ed., La production de l'espace. Paris: Anthropos, 1974.

Massey, Doreen. Space, Place and Gender. Minneapolis MN (USA): University of Minnesota Press, 1994.

Radović, Darko, and Davisi Boontharm. In the Search of Urban Quality. 100 Maps of Kuhonbutsugawa Street, Jiyügaoka. Tokyo: flick studio, 2014.

Spain, Daphne. "Gender and Urban Space." Annual Review of Sociology no. 40 (2014): 581-98.

Tsukamoto, Yoshiharu, and Momoyo Kaijima. Atelier Bow-Wow: Behaviorology. New York: Rizzoli, 2010.

Ueno, Chizuko. The Modern Family in Japan: Its Rise and Fall. Balwyn, North Victoria, Australia: Trans Pacific Press, 2009.

Van den Berg, Marguerite. "The Discursive Uses of Jane Jacobs for the Genderfying City: Understanding the Productions of Space for Post-Fordist Gender Notions." Urban Studies 55, no. 4 (2018): 751-66.

Wekerle, Gerda R. "Women in the Urban Environment," Signs 5, no. 3, supplement "Women and the American City" (1980): 188-214.

\section{Acknowledgements}

The authors would like to express their gratitude to Yoko Kihara, undergraduate student at Tsukamoto Laboratory, Tokyo, who actively collaborated in the development of this article. Many thanks to the reviewers and Prof. Dr. Laurent Stalder, Chair of the Theory of Architecture at ETH Zürich, for their final critical inputs. Also special thanks to the Jiyūgaoka Shopping Association for kindly lending us the guidebooks and to the Japanese MEXT (Ministry of Education, Culture, Sports, Science and Technology) for supporting this investigation with a Monbukagakusho Scholarship. 


\section{Credits}

Figures 1 and 4-8: () the Authors.

Figure 2: @ Noemí Gómez Lobo, Yoshiharu Tsukamoto, Diego Martín Sanchez. Data retrieved from: (a) Ministry of International Affairs and Communications, Statistics Bureau of Japan; (b) FY 2017 Annual Report on the Japanese Economy and Public Finance, Cabinet Office.

Figure 3: @ Jiyūgaoka Shopping Association.

Tables 1 and 2: @ Noemí Gómez Lobo, Yoshiharu Tsukamoto, Diego Martín Sanchez, Yoko Kihara.

Noemí Gómez Lobo is an architect, graduated at the Madrid School of Architecture (ETSAM). She has received the MEXT (Ministry of Education, Culture, Sports, Science and Technology) scholarship from the Japanese Government and is currently developing her doctoral thesis at the Tokyo Institute of Technology under the tutelage of Yoshiharu Tsukamoto. Her research focuses on the intersection between gender and the Japanese context, revealing relationships with the built environment and the architectural profession. Noemí is also co-founder of "furiistudio," a young architectural practice internationally awarded in competitions such as Europan. E-mail: noemi.globo@gmail.com

Yoshiharu Tsukamoto is an architect and founder of Atelier Bow-Wow with Momoyo Kaijima. Their practice has designed houses and public spaces in Japan, Europe and the United States. Their works have been published as The Architectures of Atelier Bow-Wow: Behaviorology (2010), and Atelier Bow-Wow - Graphic Anatomy (2014). Their urban research has been featured in many publications, such as Pet Architecture Guide Book (2002), Made in Tokyo (2007), Void Metabolism (2012) and Commonalities of Architecture (2016). "Micro Public Space," a series of critical interventions into public spaces, has been realized worldwide. Tsukamoto is professor at the Tokyo Institute of Technology, where he conducts a laboratory of urban and architectural research. He has taught as guest professor internationally at various universities, including the Harvard University GSD, Columbia University GSAPP, UCLA, Cornell University, ETH, TU-Delft, and the Royal Academy of Arts in Copenhagen. E-mail: tsukamot@arch.titech.ac.jp

Diego Martín Sánchez is an architect by Madrid School of Architecture (ETSAM), enjoyed an international mobility scholarship at the Illinois Institute of Technology, and the Pontificia Universidad Católica de Chile (Santiago, Chile). Diego was also granted with the Monbukagakusho Scholarship and is currently developing his doctoral research at Tsukamoto Laboratory. He worked in several architecture offices in fields such as publications, urban and architecture design. Diego is co-founder of "furiistudio," and currently collaborates with the Madrid City Council for urban revitalization in the downtown area. E-mail: hola@furiistudio.com 